\title{
Lecturer's Gender and Their Valuation of Student Evaluation of Teaching
}

\author{
Engku Suhaimi Engku Atek ${ }^{1}$, Hishamuddin Salim ${ }^{1}$, Zulazhan Ab. Halim ${ }^{1}$, Zailani Jusoh ${ }^{1} \&$ \\ Mohd Ali Mohd Yusuf ${ }^{2}$ \\ ${ }^{1}$ Faculty of Languages and Communication, Universiti Sultan Zainal Abidin, Malaysia \\ ${ }^{2}$ Faculty of Islamic Contemporary Studies, Universiti Sultan Zainal Abidin, Malaysia \\ Correspondence: Engku Suhaimi Engku Atek, Faculty of Languages and Communication, Universiti Sultan \\ Zainal Abidin, Kuala Terengganu 21300, Malaysia. E-mail: esuhaimi@unisza.edu.my
}

Received: January 21, 2015 Accepted: February 23, 2015 Online Published: May 28, 2015

doi:10.5539/ies.v8n6p132 URL: http://dx.doi.org/10.5539/ies.v8n6p132

\begin{abstract}
Student evaluation of teaching (SET) is carried out every semester at Malaysian universities and lecturers are evaluated based on student ratings. But very little is researched about what lecturers actually think about SET and whether it serves any meaningful purpose at all. This quantitative study involving six public universities on the East Coast of Peninsular Malaysia examines the extent to which male and female lecturers value their student evaluations of teaching (SET) and if their valuations differ significantly by gender. The study also elicits perceptions of male and female lecturers on the formative and summative functions the SET serves. A survey questionnaire comprising 29 Likert-scale items was employed to obtain data for this study. The respondents comprised 137 language instructors of English and Arabic proficiency courses for undergraduates from those six universities. Data were analysed descriptively and inferentially using descriptive statistics and independent sample t-test. The study produces several outcomes. The study found that although male lecturers value SET higher than their female colleagues, no significant differences are observed in their valuation of SET by gender. Also of significance is the observation that lecturers of both gender found SET more useful for formative rather than summative functions. This study itself is significant in order to understand the lecturers' perceptions of SET which will stimulate further discussions and thinking around the issue of strengthening the teaching practice as SET itself can be an effective tool for lecturer's development if lecturers themselves understand and value the process.
\end{abstract}

Keywords: student evaluation of teaching, Malaysian universities, gender, formative, summative

\section{Introduction}

Iyamu and Aduwa (2005) define student evaluation of teaching (SET) as a periodic evaluation of teacher's performance by students which involves systematic gathering and analysis of information on the basis of which decisions are taken regarding the effectiveness, efficiency and/or desire of the university to promote effective learning. It is known that higher education has always placed the importance of evaluating academic staff to ensure that they are teaching in ways most conducive to learning (Kogan, Schoenfeld-Tacher, \& Hellyer, 2010). Meanwhile, it has been assumed that students are in the best position to know whether the teaching they receive is adequate and whether they are learning (Clayson \& Haley, 1990).

SET serves a range of purposes, both formative and summative. SET serves purposes ranging from diagnostic feedback in order to improve teaching to tenure and promotion (Marsh, 1984). The formative functions of SET include the improvement of classroom instruction, student learning, and the fostering of professional growth of the teacher. For summative purposes, the results of SET are used for administrative/personnel decisions like promotion, demotion, salary increase, dismissal, awards and/or meeting public accountability demands.

A majority of educational institutions incorporate some form of student evaluation to assess teaching effectiveness (Comm \& Manthaisel, 1998). In Malaysia, almost all universities use student evaluation as a measure of lecturers' performance (Harun, Dazz, Saaludin, \& Che-Wan-Ahmad, 2011). Most lecturers have conducted a student evaluation at some stage during their teaching careers (Sulong, 2014). However, very few studies have been carried out to examine how lecturers view student evaluation of them although student rating 
can have a significant impact on them in the way they teach and also in their future career development. As argued by Kogan et al. (2010), studies linking SET to their impact on lecturers have largely been neglected. There are certainly valid issues confronting lecturers with regards to SET and they need addressing. Among these are: What do lecturers feel about SET? Do they value SET? What formative and summative needs does SET serve? Do lecturers perceive SET useful for formative and summative purposes?

The general aim of this study is therefore to explore the feelings and thoughts that university male and female lecturers have about their student evaluations and whether these differ by factor of gender. Specifically, the research embarks on the following objectives: (1) to investigate the extent to which male and female university lecturers value SET; (2) to find out whether perceptions of SET among university lecturers differ significantly by factor of gender; (3) to determine the formative and summative functions of SET; and (4) to find out whether the formative or summative purposes of SET are perceived more useful by lecturers of both gender.

In order to address the objectives of this study, the following research questions are formulated: (1) To what extent do male and female university lecturers value SET?; (2) Do university lecturers' perceptions of SET differ significantly by factor of gender?; (3)What formative and summative functions does SET serve?; (4) Do male and female lecturers perceive SET more useful for formative or summative functions?

\section{Student Evaluation of Teaching}

Jackson (1998) identifies nine approaches to teacher evaluation: classroom observation, students' ratings, peer-rating, self-rating, teacher interview, parents' rating, students' achievement, competency tests and indirect measures. Studies involved with measures of evaluating teacher's teaching competencies have consistently employed some of these approaches (Otote, 2004). Of all these approaches, students' ratings or SET has traditionally been the primary source of assessing teaching in higher education (Weinberg, Hashimoto, \& Fleisher, 2009). This is supported by Zabaleta (2007) who argues that SET is an almost universally accepted method of gathering information on teaching.

Formal student evaluation systems have been part of the higher education setting for decades and have prompted extensive discussion in the literature about their values and usefulness for teachers and learners (Smock \& Crooks, 1973; McKeachie, 1990; Beran \& Rokosh, 2009; Aleamoni, 1987; Nasser \& Fresko, 2002; Arthur, 2009). The literature on student evaluation of teaching effectiveness can be traced back to the 1920's and earlier (Marsh \& Bailey, 1993). From the 1970's onwards, the use of student evaluations saw a dramatic expansion, culminating with the administrative use of student evaluations in the 1980's. According to Ory (1991), many college and university administrators who were satisfied with the validity and reliability of student ratings began to view student ratings as a useful and necessary indicator of an instructor's teaching ability.

Student evaluation serves many functions, ranging from diagnostic feedback to improve teaching to measure of evidence for tenure and promotion (Marsh, 1984). Richmond (2003) and Clifford (1999) argue that student opinion is of particular importance because it represents an important addition to the data customarily used to judge competence of lecturers. Machingambi and Wadesango (2011) argue that it is essential to know the strengths of teachers and those aspects of their practice which could be further developed. In this perspective, the student evaluation is seen as a key step in the drive to improve the effectiveness of teaching and learning and raise educational standards (Santiago \& Benavides, 2009). Hussin, Jusoff, and Wan-Omar (2008) posited that students' perceptions are important in assessing and evaluating the quality of teaching. Gold (2001) regards SET as a useful tool to improve classroom instruction, student learning, and to foster professional growth of the teacher, and also the results of such evaluation are used for administrative/personnel decisions.

Literature available suggests that lecturers' perceptions of student evaluation of their instructional practices are somewhat mixed. Some studies found SET to be useful and beneficial to the lecturers (Cohen, 1981; Isiaka, 1998; Smith \& Anderson, 2003). A study by Christopher and Shane (2007) reported that the respondents in their research viewed student evaluation of teaching as appropriate and necessary.

Other studies, however, return a less favourable attitude towards SET. Studies by Machingambi and Wadesango (2011), Cross (2002), and Richmond (2003) have concluded that academicians generally have a negative disposition of SET. A likely explanation is that lecturers are apprehensive about the potential academic and professional inadequacies that may be exposed by student evaluations. Urevbu (1997) argues that most lecturers are not convinced that university students are competent enough to evaluate their lecturers. Kilpatrick (1997), Imogie (2000), and Cross (2002) found that junior and less experienced lecturers tend to have a more negative disposition towards SET than senior academics. Iyamu and Aduwa (2005), who carried out a survey in Nigerian public universities to investigate how lecturers perceived the importance of student evaluation, posited that, generally, lecturers are apprehensive of student evaluation, especially when it is used for promotion or salary 
increment purposes.

Research pertaining to performance feedback also suggests that gender can impact how people view and incorporate feedback, and women can be more receptive to the opinions of others. Lungren and Rudawsky (1998) argue that the socialisation process of women includes the tendency to consider the feelings and perceptions of others. This is interpreted by Kogan et al. (2010) to mean women are more "collectivist" while men are more "individualists" or "autonomous", implying that men are more resistant to the influence of others. This is in tune with Yusuf, Ajidagba, Agbonna and Olumurin (2010) who found there were significant differences between the perception and gender. They posited that male and female lecturers have different views of student evaluation and concluded that female lecturers tend to be more sensitive to the harm that such practice might inflict on their career than their male counterpart. On the contrary, Idaka, Joshua, and Kritsonis (2006) and Olatoye and Aanu (2011) found no such differences in perception between male and female lecturers. Other studies (Dweck \& Bush, 1976; Nicholls 1975) found the impact on males and females to be similar when the feedback is objective but when the feedback is subjective, females evaluate themselves more negatively than males.

\section{Methodology}

A research design involving a quantitative method was adopted for this study. Six public universities on the East Coast of Peninsular Malaysia were chosen for this study: Universiti Sultan Zainal Abidin (UniSZA), Universiti Malaysia Terengganu (UMT), Universiti Malaysia Kelantan (UMK), Universiti Malaysia Pahang (UMP), Universiti Teknologi MARA, Kelantan Campus (UiTM Kelantan) and Universiti Teknologi MARA, Terengganu Campus (UiTM Terengganu).

A questionnaire was administered to 137 samples out of a population of 220 academics who had taught English and Arabic language proficiency courses at the undergraduate level in the first semester of the 2012/2013 academic session and who had obtained at least one SET feedback for their course(s). These language instructors included male and female teachers and lecturers of various ranks, age and length of service.The sample size of 137 used in this study fulfils the determination of the sample size formula presented by Krejcie and Morgan (1970).

The questionnaire formulated for this research was adopted from Machingambi and Wadesango (2011). The questionnaire is comprised of 29 items, divided into four sections. Section A, consisting of nine items, included reference to demographic charecteristics such as gender, teaching discipline, institution, rank, length of service, age and course(s) taught. Sections B, C and D used a five-point scale of Strongly Agree, Agree, Neutral, Disagree and Strongly Disagree. Section B, comprising of ten items, pertained to the value and need of student evaluation by lecturers. Section C, made up of five items, related to the formative needs of SET. Items 25-29 in Section D related to the use of student evaluation for summative purposes. The questionnaire was printed in two versions: English and Malay language. The English version was administered to English language lecturers while the Malay language print was for lecturers of Arabic language.

The study used the Cronbach alpha method to determine the index reliability of the questionnaire. According to Tan (2007), Cronbach's alpha test is a reliability test that measures the internal consistency and stability of the multi-item scales. The test itself is based on the correlation between variables. The closer the estimated Cronbach's alpha coefficient approaches to the value of 1 , the higher the reliability of the multi-item scales. Alpha value of less than 0.6 is considered poor, 0.6 and 0.7 is acceptable, 0.7 and 0.8 indicates good reliability and above 0.9 indicates excellent (George \& Mallery, 2011). A pilot study was carried out on 30 samples to determine the reliability of the questionnaire. The reliability of the questionnaire was valued at 0.917 . Implications of the value obtained show that the questionnaire has excellent reliability.

From the questionnaires returned, data were analysed descriptively and inferentially using descriptive statistics and independent sample t-test. For objectives 1, 3 and 4, data were analysed descriptively using mean and standard deviation. Interpretations of mean scores shown in Table 1 were used to interpret the average mean score of each item. 
Table 1. Mean score interpretation

\begin{tabular}{lc}
\hline Mean Score & Description \\
\hline $1.00-2.33$ & Low \\
$2.34-3.66$ & Moderate \\
$3.67-5.00$ & High
\end{tabular}

Source: Barnett (2000), Jamil (2002), Jainabee (2005) and Mumtaz (2008).

For objective 2, independent sample t-test was used to analyse data for significant differences between gender.

\section{Results}

The respondents in this study comprised 137 male and female English language and Arabic language lecturers of various ranks, age and length of service from six participating universities on the East Coast of Peninsular Malaysia: UniSZA, UMT, UMP, UMK, UiTM Terengganu and UiTM Kelantan.

Table 2 summarises the demographic profile of the respondents by gender. As indicated in the table, almost three-quarter of the respondents are female (74.6\%). Male respondents $(25.6 \%)$ are therefore significantly outnumbered by female respondents.

Table 2. Demographics of respondents

\begin{tabular}{lcc}
\hline Gender & $\mathrm{N}$ & Percentage \\
\hline Male & 35 & 25.6 \\
Female & 102 & 74.4 \\
Total & 137 & 100.0 \\
\hline
\end{tabular}

\subsection{To What Extent Do Lecturers Value SET?}

One of the key objectives of this study is to find out the extent to which university lecturers value SET. This is addressed by items 10-19 of the questionnaire. Their responses are summarised in Table 3. Overall, lecturers are found to value SET moderately $(\mathrm{M}=3.63, \mathrm{SD}=.74)$. This suggests that while they may value $\mathrm{SET}$, they do not regard SET highly. The items mean scores range from a high of 3.93 (Item 13) to a low of 3.30 (Item 12). Five items (Items 10, 13, 14, 17 and 18) obtain high valuation while another six (Items 10, 11, 15, 16, 18, 19) are rated moderately. This clearly shows that lecturers' support for SET is limited to certain areas only. On the positive side, SET actually makes the lecturers more prepared for their teaching (Item 13: $\mathrm{M}=3.92, \mathrm{SD}=.95$ ), lecturers also respond positively if students are asked to evaluate their lecturers (Item 10: $\mathrm{M}=3.82, \mathrm{SD}=.87$ ), lecturers will become more committed to their job (Item 17: $\mathrm{M}=3.69, \mathrm{SD}=.93$ ), lecturers will be more punctual to class (Item 14: $\mathrm{M}=3.68, \mathrm{SD}=1.10$ ) and lecturers become more innovative in their teaching (Item 18: $\mathrm{M}=3.67$, $\mathrm{SD}=.96)$. 
Table 3. SET valuation by item

\begin{tabular}{|c|c|c|c|c|c|}
\hline Item no. & Item & $\mathrm{N}$ & Mean & SD & Interpretation \\
\hline 10 & $\begin{array}{l}\text { The idea of students evaluating their lecturer is } \\
\text { acceptable }\end{array}$ & 137 & 3.82 & .87 & High \\
\hline 11 & $\begin{array}{l}\text { University students are responsible enough to } \\
\text { evaluate their lecturers }\end{array}$ & 137 & 3.52 & .95 & Moderate \\
\hline 12 & $\begin{array}{l}\text { Students possess good value judgments to evaluate } \\
\text { their lecturers }\end{array}$ & 137 & 3.30 & .90 & Moderate \\
\hline 13 & $\begin{array}{l}\text { Lecturers will be more prepared for their teaching if } \\
\text { evaluated by students }\end{array}$ & 137 & 3.92 & .95 & High \\
\hline 14 & $\begin{array}{l}\text { Lecturers will be more punctual to class if they know } \\
\text { that their students will evaluate them }\end{array}$ & 137 & 3.68 & 1.10 & High \\
\hline 15 & $\begin{array}{l}\text { Lecturers will be more transparent to students if they } \\
\text { know that they will be evaluated by their students }\end{array}$ & 137 & 3.55 & 1.01 & Moderate \\
\hline 16 & $\begin{array}{l}\text { Student evaluation of lecturers helps improve } \\
\text { lecturer-student relationship }\end{array}$ & 137 & 3.50 & .89 & Moderate \\
\hline 17 & $\begin{array}{l}\text { Student evaluation of lecturers helps lecturers to be } \\
\text { more committed to their jobs }\end{array}$ & 137 & 3.69 & .93 & High \\
\hline 18 & $\begin{array}{l}\text { Lecturers will be more innovative in their teaching if } \\
\text { they are evaluated by their students }\end{array}$ & 137 & 3.67 & .96 & High \\
\hline \multirow[t]{2}{*}{19} & $\begin{array}{l}\text { Lecturers will be more disciplined generally if they } \\
\text { know that their students will evaluate them }\end{array}$ & 137 & 3.60 & 1.00 & Moderate \\
\hline & Overall & 137 & 3.63 & .74 & Moderate \\
\hline
\end{tabular}

An analysis between gender in Table 4 shows that male lecturers value SET highly $(\mathrm{M}=3.75, \mathrm{SD}=.60)$. In comparison, their female colleagues only observe a moderate valuation of SET $(\mathrm{M}=3.58, \mathrm{SD}=.78)$. This is clearly an indication that male lecturers adopt a more positive outlook of SET. In other words, male lecturers tend to be more accommodating of SET and they see it as a positive thing.

Table 4. SET valuation by gender

\begin{tabular}{lcccc}
\hline Gender & $\mathrm{N}$ & Mean & $\mathrm{SD}$ & Interpretation \\
\hline Male & 35 & 3.75 & .60 & High \\
Female & 102 & 3.58 & .78 & Moderate \\
Overall & 137 & 3.63 & .74 & Moderate \\
\hline
\end{tabular}

\subsection{Are There Significant Differences in SET Valuation by Factor of Gender?}

Another objective of the study is to find out whether different gender has an impact in the valuation of SET. To do this, the research asks if factor of gender results in different perceptions of SET among university lecturers. To measure the impact of gender on their perceptions of SET, an independent-samples t-test was carried out. Results are presented in Table 5.The findings indicate that gender difference is non-significant in the way male and female lecturers perceive SET though male lecturers are clearly more receptive towards SET.

Table 5. Difference in SET valuation by gender

\begin{tabular}{llllll}
\hline Gender & $\mathrm{N}$ & Mean & SD & $t$ & Sig. (2-tailed) \\
\hline Male & 35 & 3.75 & .60 & & \\
Female & 102 & 3.58 & .78 & 1.263 & .210 \\
\hline
\end{tabular}




\subsection{What Formative and Summative Functions Does SET Serve?}

The third objective of this study seeks to find out what formative and summative functions SET serves. In order to address this objective, lecturers were asked to rate in their questionnaire a list of items on the basis of their formative and summative functions.

The formative functions of SET are addressed by Items 20-24 of the questionnaire. Table 6 summarises their response. Data from Table 6 shows that lecturers have high opinions of all the statements, with mean scores between 3.84 and 4.01, indicating that they are fully supportive of the use of SET for self-reflection and diagnostic feedback in order to enhance their teaching and professional growth. Data analysis shows that Item 24, "student evaluation report help lecturers evaluate themselves" to be most useful or relevant $(\mathrm{M}=4.01, \mathrm{SD}=.80)$. This is followed, in the order of importance or usefulness, by Item 21, "Results of student evaluation are needed to improve classroom instruction" $(\mathrm{M}=3.99, \mathrm{SD}=.79)$, Item 20 , "Feedback on students' evaluation helps lecturers to improve their teaching" $(\mathrm{M}=3.98, \mathrm{SD}=.86)$, Item 22 , "Results of student evaluation are used to improve students' learning" ( $\mathrm{M}=3.88, \mathrm{SD}=.73)$ and Item 23 , "Results of student evaluation are used to foster professional growth of lecturers" $(\mathrm{M}=3.84, \mathrm{SD}=.83)$.

Table 6. Formative functions of SET

\begin{tabular}{llcccc}
\hline Item no. & Item & $\mathrm{N}$ & Mean & SD & Interpretation \\
\hline 20 & $\begin{array}{l}\text { Feedback on students' evaluation helps lecturers } \\
\text { to improve their teaching }\end{array}$ & 137 & 3.98 & .86 & High \\
21 & $\begin{array}{l}\text { Results of student evaluation are needed to } \\
\text { improve classroom instruction }\end{array}$ & 137 & 3.99 & .79 & High \\
22 & $\begin{array}{l}\text { Results of student evaluation are used to improve } \\
\text { students' learning }\end{array}$ & 137 & 3.88 & .73 & High \\
23 & $\begin{array}{l}\text { Results of student evaluation are used to foster } \\
\text { professional growth of lecturers } \\
\text { Student evaluation reports help lecturers to }\end{array}$ & 137 & 3.84 & .83 & High \\
evaluate themselves & 4.01 & .80 & High \\
Overall & & 137 & 3.94 & .70 & High \\
\hline
\end{tabular}

An analysis by gender in Table 7 shows that both male and female lecturers rate SET highly for their formative purposes. Both genders produce identical mean scores of 3.94, indicating a similar positive outlook. This is clear evidence that both genders perceive SET as a useful tool for formative purposes.

Table 7. Formative functions of SET by gender

\begin{tabular}{lcccc}
\hline Gender & $\mathrm{N}$ & Mean & SD & Interpretation \\
\hline Male & 35 & 3.94 & .64 & High \\
Female & 102 & 3.94 & .72 & High \\
Overall & 137 & 3.94 & .70 & High \\
\hline
\end{tabular}

The summative functions of SET are addressed by Items 25-29 of the questionnaire. A summary of their response is shown in Table 8 where lecturers rate the use of SET for summative purposes moderately $(M=3.18$, $\mathrm{SD}=1.05)$. A closer analysis shows that the lecturers observe moderate perceptions for all the five statements, with mean scores between 2.88 (Item 27) and 3.38 (Item 28), indicating that they do not regard SET as a very useful tool for the purposes of promotion of lecturers $(\mathrm{M}=3.13, \mathrm{SD}=1.23)$, salary increase of lecturers $(\mathrm{M}=2.88$, $\mathrm{SD}=1.23)$, decisions on lecturer's retention $(\mathrm{M}=3.21, \mathrm{SD}=1.17)$, administrative decisions $(\mathrm{M}=3.29, \mathrm{SD}=1.04)$ and selecting lecturers for the "Best Lecturer" award in the faculty $(\mathrm{M}=3.38, \mathrm{SD}=1.20)$. This is in agreement with studies on SET carried out in Nigerian universities by Braskamp and Ory (1994). They established that lecturers were mostly critical of SET because of the possible damage it may inflict on their teaching career. Thus lecturers are seen to be less favourable on the practice of deciding issues of promotion, salary and tenure on the 
basis of anonymous student evaluations.

Table 8. Summative functions of SET

\begin{tabular}{|c|c|c|c|c|c|}
\hline Item no. & Item & $\mathrm{N}$ & Mean & SD & Interpretation \\
\hline 25 & $\begin{array}{l}\text { Results of student evaluation are needed for } \\
\text { administrative decisions }\end{array}$ & 137 & 3.29 & 1.04 & Moderate \\
\hline 26 & $\begin{array}{l}\text { Student evaluation results should be used for the } \\
\text { promotion of lecturers }\end{array}$ & 137 & 3.13 & 1.23 & Moderate \\
\hline 27 & $\begin{array}{l}\text { Student evaluation results are needed for salary } \\
\text { increase of lecturers }\end{array}$ & 137 & 2.88 & 1.23 & Moderate \\
\hline 28 & $\begin{array}{l}\text { Student evaluation results are needed to select } \\
\text { the best lecturers for awards in the faculty }\end{array}$ & 137 & 3.38 & 1.20 & Moderate \\
\hline \multirow[t]{2}{*}{29} & $\begin{array}{l}\text { Results of student evaluations are used for } \\
\text { decisions on lecturers' retention }\end{array}$ & 137 & 3.21 & 1.17 & Moderate \\
\hline & Overall & 137 & 3.18 & 1.05 & Moderate \\
\hline
\end{tabular}

An analysis by gender in Table 9 shows that both gender rate moderately the use of SET for summative functions but male lecturers $(\mathrm{M}=3.44, \mathrm{SD}=.99)$ are found to have a more positive disposition than female lecturers $(\mathrm{M}=3.09, \mathrm{SD}=1.06)$.

Table 9. Summative functions of SET by gender

\begin{tabular}{lcccc}
\hline Gender & $\mathrm{N}$ & Mean & $\mathrm{SD}$ & Interpretation \\
\hline Male & 35 & 3.44 & .99 & Moderate \\
Female & 102 & 3.09 & 1.06 & Moderate \\
Overall & 137 & 3.18 & 1.05 & Moderate \\
\hline
\end{tabular}

\section{Discussion}

Results from this study suggest that although both male and female university lecturers do not value SET highly, they do not totally object to the use of SET as a form of teacher evaluation as indicated by their moderate valuation of SET. In fact, both male and female lecturers have very positive dispositions of certain aspects of SET especially those pertaining to their formative functions. These findings support studies by Santiago and Benavides (2009), Gold (2001), Cohen (1981), and Christopher and Shane (2007) in which SET is seen as a key step to improving teaching and learning effectiveness. Among others, university lecturers of both genders are highly supportive of the idea of students evaluating their lecturers, indicating that for pedagogical purposes, lecturers agree that students do have a role to play in evaluating their classroom teaching. There are other highly positive values of SET that the lecturers have identified: lecturers will be more prepared if they know they are evaluated by their students, lecturers will be more punctual to class, lecturers will be more committed to teaching, and lecturers will be more innovative in class.

However, results in other areas are found to be less encouraging. Male and female lecturers' moderate valuation of these aspects is an indication that both gender find SET to contain elements that are seen to be less desirable to them. Their views seem to concur with studies carried out by Machingambi and Wadesango (2011), Cross (2002) and Richmond (2003) in which academicians generally have a negative disposition of SET. This is especially true with regards to students being responsible enough to evaluate them, and students possess good value judgments to evaluate their lecturers. This also concurs with Urevbu (1997) who argue that most lecturers are not convinced that students are competent enough to evaluate their lecturers.

Interestingly, this study has shown that male lecturers are found to adopt a more positive disposition of SET even though no significant differences are observed in the lecturers' valuations of SET by factor of gender. That female lecturers adopt a more negative perception of SET seems to confirm the study carried out by Yusuf et al. (2010). On the non-significant difference in perceptions by factor of gender, this finding is in tune with Idaka et 


\section{al. (2006), and Olatoye and Aanu (2011).}

SET is also found to have useful formative functions. The use of SET for formative purposes has resonated well with the lecturers, both male and female. This is evident in the findings where SET's formative functions are rated highly by both gender. Additionally, lecturers strongly believe that student evaluations help lecturers to evaluate themselves, improve classroom instruction, improve teaching, student's learning, and to foster the professional growth of lecturers. However, the usefulness of SET for summative purposes is debatable as indicated by the combined male and female lecturers' moderate perceptions on SET's summative functions. This is especially so when SET results are needed for salary increase of lecturers, the promotion of lecturers, and decisions on lecturer's retention. The lecturers' perceptions are marginally better when asked if SET should be used for administrative decisions, and to select the best lecturer in the faculty.

Another important outcome of this research is that lecturers of both genders have a strong inclination towards SET as a tool for formative purposes but they are less disposed about SET being used for the summative purposes of promotion, determining salary increments and for making decisions on lecturers' retention. This resonates with arguments put forward by some educationists that an assessment form that contains a few items that students rate on a five-point scale at the end of the semester can hardly measure accurately effective teaching (Iyamu, 1998). Thus, it would probably be unwise if SET is used as the deciding factor, for instance, in the promotion and retention of lecturers.

\section{Conclusion and Implications}

This research has several implications. SET, if properly administered, can be a useful tool for evaluating a lecturer's pedagogical performance as attested by the results of this study. SET, if employed for the purpose of formative needs allows lecturers to evaluate student feedback of their teaching in order to improve teaching instruction which is a prerequisite for their professional growth. Pedagogically, the feedback from students can be used to improve instruction and enhance the professional growth of lecturers (Salah-ud-din, Mearaj-ud-din \& Muhammad-Shah, 2006; Joshua, 1999). This may certainly result in better teaching practices because lecturers are aware that they are evaluated by their own students every semester. The university and the students benefit from having SET but the lecturers benefit the most. The benefits to universities and students, and especially lecturers, include the potential to improve teaching, reduced uncertainty pertaining to student perceptions, and increased self-esteem and confidence in teaching among lecturers (Kogan et al., 2010).

Since this study has shown that lecturers of both genders do not value SET highly for summative purposes, the university management should not rely solely on SET for the purposes of the retention, promotion and salary increase of the academic staff. Instead, the university management should consider employing other instruments that can better measure the performance of lecturers.

This study is significant because its outcome can yield potential benefits to the university lecturers, students and the university itself. As this study seeks to engage university lecturers in order to understand their feelings with regards to SET, knowledge of their perceptions is critical as it will stimulate further discussions and thinking around the issue of strengthening the teaching and evaluation of teaching practices. Through this study, university lecturers are given a voice and and an active role in the evaluation process and it is hoped that they will be more likely to accept the results from SET. The evaluation of university lecturers by students can only be considered an effective tool for their development if lecturers themselves understand and value the process.

\section{Acknowledgements}

We would like to thank the Centre for Research and Innovation Management (CRIM), Universiti Sultan Zainal Abidin, Malaysia, for affording us the fund to carry out and complete this research.

\section{References}

Aleamoni, L. M. (1987). Typical faculty concerns about student evaluation of teaching. New Directions for Teaching and Learning, 31, 25-31. http://dx.doi.org/10.1002/t1.37219873105

Arthur, L. (2009). From performativity to professionalism: Lecturers' responses to student feedback. Teaching in Higher Education, 14(4), 441-454. http://dx.doi.org/10.1080/13562510903050228

Beran, T. N., \& Rokosh, J. L. (2009). Instructors' perspectives on the utility of student ratings of instruction. Instructional Science, 37(2), 171-184. http://dx.doi.org/10.1007/s11251-007-9045-2

Braskamp, L. A., \& Ory, J. C. (1994). Assessing Faculty Work. San Francisco: Jossey Bass.

Christopher, K. S., \& Shane, P. D. (2007). Pharmacy students' perceptions of a teaching evaluation process. American Journal of Pharmaceutical Education, 71(1). 
Clayson, D. E., \& Haley, D. A. (1990). Student evaluations in marketing: What is actually being measured? Journal of Marketing Education, 27, 122-129. http://dx.doi.org/10.1177/0273475304273525

Clifford, R. (1999). Quality control in college teaching.Issues in College Teaching, 9(2), 11-20.

Cohen, P. A. (1981). Student ratings of instruction and student achievement: A meta analysis of multi-section validity studies. Review of Educational Research, 51, 281-309. http://dx.doi.org/10.3102/00346543051003281

Comm, C. L., \& Manthaisel, D. F. X. (1998). Evaluating teaching effectiveness in America's business schools: Implications for service marketers. Journal of Professional Service Marketing, 16, 163-170. http://dx.doi.org/10.1300/J090v16n02_09

Cross, R. (2002). Measuring Quality in Education. New York: El-Kley.

Dweck, C. S., \& Bush, E. S. (1976). Sex differences in learned helplessness: I. Differential debilitation with peer $\begin{array}{lllll}\text { and adult } & \text { evaluators. Developmental }\end{array}$ http://dx.doi.org/10.1037/0012-1649.12.2.147

George, D., \& Mallery, P. (2011). IBM SPSS Statistics 19 Step by Step: A simple guide and reference (12th ed.). Pearson.

Gold, R. (2001). Evaluation of instruction. Educational Studies, 15(1), 31-42.

Harun, S., Dazz, S. K., Saaludin, N., \& Che-Wan-Ahmad, W. S. (2011). Lecturer's perception on student evaluation at Universiti Kuala Lumpur. Enhancing Learning: Teaching and Learning Conference (pp. 1-10).

Hussin, Z., Jusoff, K., \& Wan-Omar, M. (2008). Perception of Students Teaching Quality Determinants and Effectiveness. Asian Social Science, 4(12), 113-117.

Idaka, I. I., Joshua, M. T., \& Kritsonis, W. A. (2006). Attitude of academic staff in Nigerian tertiary educational institutions to student evaluation of instruction (SEI). National Forum of Educational Administration and Supervision Journal, 23(4).

Imogie, A. I. (2000). Do you know who is teaching your child? Benin City: University of Benin Press.

Isiaka, B. T. (1998). Teachers' perception of students' evaluation of teaching effectiveness. Lagos Journal of Education (Special edition), 6-11.

Iyamu, E. O. S. (1998). Assessment of the inquiry-teaching competences of social studies teachers in junior secondary schools in Edo State (Unpublished PhD thesis). University of Benin, Benin City, Nigeria.

Iyamu, E. O. S., \& Aduwa, J. (2005). Assessment of the Inquiry-Teaching Competences of Social Studies Teachers in Junior Secondary Schools in Edo State. University of Benin: Benin.

Iyamu, E. O. S., \& Aduwa, J. (2005). Lecturers's perception of students' evaluation in Nigerian universities. International Education Journal, 6(5), 619-625.

Jackson, M. (1998). Teacher characteristics and teaching effectiveness. Studies in Education, 12, 101-112.

Joshua, M. T. (1999). Faculty evaluation as a panacea for enhancing quality teaching in Nigeria's tertiary education. Nigerian Education Journal, 2(2), 97-111.

Kilpatrick, A. (1997). Another look at teaching Evaluation in American Junior Colleges. California: El Camino College.

Kogan, L. R., Schoenfeld-Tacher, R., \& Hellyer, P. W. (2010). Student evaluations of teaching: Perceptions of faculty based on gender, position and rank. Teaching in Higher Education, 15(6), 623-636. http://dx.doi.org/10.1080/13562517.2010.491911

Krejcie, R. V., \& Morgan, D. W. (1970). Determining sample size for research activities. Educational and Psychological Measurements, 30, 607-610.

Lungren, D. C., \& Rudawsky, D. J. (1998). Female and male college students' responses to negative feedback from parents and peers. Sex Roles, 39, 409-429. http://dx.doi.org/10.1023/A:1018823126219

Machingambi, S., \& Wadesango, N. (2011). University lecturers' perceptions of students evaluation of their instructional practices. Anthropologist, 13(3), 167-174.

Marsh, H. W. (1984). Students' evaluations of university teaching: Dimensionality, reliability, validity, potential biases and utility. Journal of Educational Psychology, 76, 707-754. http://dx.doi.org/10.1037/0022-0663.76.5.707 
Marsh, W., \& Bailey, M. (1993). Multidimensional students' evaluations of teaching effectiveness. Journal of Higher Education, 6, 1-18. http://dx.doi.org/10.2307/2959975

McKeachie, W. (1990). Research on college teaching: The historical background. Journal of Educational Psychology, 82(2). 189-200. http://dx.doi.org/10.1037/0022-0663.82.2.189

Nasser, F., \& Fresko, B. (2002). Faculty views of student evaluation of college teaching. Assessment and Evaluation in Higher Education, 27(2), 187-198. http://dx.doi.org/10.1080/02602930220128751

Nicholls, J. G. (1975). Causal attribution and other achievement-related cognitions: Effects of task outcome, attainment value and sex. Journal of Personality and Social Psychology, 31, 379-389. http://dx.doi.org/10.1037/h0076505

Olatoye, R. A., \& Aanu, E. M. (2011). Senior secondary school science teachers' perception of using students to evaluate teaching effectiveness. Journal of Emerging Trends in Education Research and Policy Studies, 164-170.

Ory, J. C. (1991). Changes in evaluating teaching in higher education. Theory into Practice, 30(1), 30-36. http://dx.doi.org/10.1080/00405849109543473

Otote, C. O. (2004). Assessment of the Affective Evaluation Competences of Social Studies Teachers in Junior Secondary Schools in Edo State (Unpublished PhD thesis). University of Benin, Benin City, Nigeria.

Richmond, E. (2003). Looking at good teaching. Educational Evaluation, 35(1), 48-59.

Ronald Jr, D. F., \& Schonlau, M. (2002). Advantages and Disadvantages of Internet Research Surveys: Evidence from the Literature. Field Methods, 14(4), 347-367.

Salah-ud-din, K., Mearaj-ud-din, \& Muhammad-Shah. (2006). Development of a reliability and valid instrument for the evaluation of performance of directors of physical education. Gomal University Journal of Research, 22, 29-36.

Santiago, P., \& Benavides, F. (2009). Teacher Evaluation, A Conceptual Framework and Examples of Country Practices. Paper presented at the OECD-Mexico Workshop towards a Teacher Evaluation Framework, Mexico, 12 August 2009.

Smith, S., \& Anderson, L. O. (2003). Student evaluation practice in selected American Colleges. International Journal of Education, 22(1), 81-92.

Smock, H. R., \& Crooks, T. J. (1973). A plan for the comprehensive evaluation of college teaching. Journal of Higher Education, 44, 577-586. http://dx.doi.org/10.2307/1980392

Sulong, M. S. (2014). Lecturers' perception on teaching evaluation: Selection of research instruments. The Online Journal of Quality in Higher Education, 1(2), 36-44.

Tan, J. H. (2007). Statistical techniques in business research: a practical approach. Malaysia: Prentice Hall.

Urevbu, A. O. (1997). Creating the school we deserve: Reflections on Education, Pedagogy and Curriculum. Benin City: University of Benin.

Weinberg, B. A., Hashimoto, M., \& Fleisher, B. M. (2009). Evaluating teaching in higher education. Journal of Economic Education, 40, 227-254. http://dx.doi.org/10.3200/JECE.40.3.227-261

Yusuf, A. R., Ajidagba, U. A. R., Agbonna, S. A., \& Olumurin, C. O. (2010). University teachers' perception of the effects of students evaluation of teaching on lecturers instructional practices in Nigeria. Proceedings of the 1st International Conference of Collaborational of Education Faculties in West Africa (CEFWA) (pp. $1-16)$.

Zabaleta, F. (2007). The use and misuse of student evaluations of teaching. Teaching in Higher Education, 12, 55-76. http://dx.doi.org/10.1080/13562510601102131

\section{Copyrights}

Copyright for this article is retained by the author(s), with first publication rights granted to the journal.

This is an open-access article distributed under the terms and conditions of the Creative Commons Attribution license (http://creativecommons.org/licenses/by/3.0/). 